\title{
ARTIKELEN
}

\section{Het Wetsvoorstel burgerschapsopdracht}

\author{
Jaco van den Brink
}

Het Wetsvoorstel burgerschapsopdracht ${ }^{1}$ vraagt om grondige bezinning. Op het eerste gezicht gebeurt hier iets wat historisch is voor de Nederlandse democratische rechtsstaat: de wetgever duidt publiek-morele basiswaarden die zodanig fundamenteel zijn voor onze samenleving dat alle kinderen en jongeren die waarden moeten meekrijgen op school. Het voorstel houdt in dat deze waarden in de onderwijswetten aangeduid worden, vergezeld van de verplichting voor elke school om hiervoor respect bij te brengen, en bovendien te zorgen voor een cultuur die in overeenstemming is met deze waarden. De wetgever, en daarna het ministerie en de Onderwijsinspectie, stellen dus juridisch bindende voorschriften over publiek-morele opvattingen die op school moeten worden uitgedragen. Het gaat om 'de basiswaarden van de democratische rechtsstaat, zoals verankerd in de Grondwet, en de universeel geldende fundamentele rechten en vrijheden van de mens'. De verplichting geldt als 'bekostigingsvoorwaarde': bij niet-naleving verspeelt een instelling dus haar recht op publieke bekostiging.

Is het inderdaad een ingrijpend wetsvoorstel? De minister relativeert dit. Volgens de memorie van toelichting en het Nader rapport van de minister lijkt het niet de bedoeling van het kabinet om basiswaarden voor te schrijven die omstreden zijn in de samenleving en de bestaande diversiteit aan richtingen en bijbehorende waardestelsels inperken. ${ }^{2}$ De twijfels over het Cornelius Haga Lyceum daargelaten, lijkt het wetsvoorstel vooral bedoeld om scholen in positieve zin een steun in de rug te bieden bij het werken aan democratische vorming van de leerlingen.

Niettemin vraagt het om rekenschap, nu hiermee voor het eerst het woord 'basiswaarden' in de wetgeving terechtkomt. De minister acht het immers ook noodzakelijk om inhoudelijke (morele) sturing te geven aan het burgerschapsonderwijs. De bestaande burgerschapsbepaling ${ }^{3}$ die geen inhoudelijke waardering van de democratische rechtsstaat voorschrijft, wordt nu geacht daardoor te veel ruimte

1 Voorstel van Wet tot wijziging van een aantal onderwijswetten in verband met verduidelijking van de burgerschapsopdracht aan scholen in het funderend onderwijs, Tweede Kamerstuknummer 35352.

2 Kamerstukken II 2019/20, 35352, 3, MvT, p. 9; Kamerstukken II 2019/20, 35352, 4, Nader rapport, p. 10.

3 Het te wijzigen artikellid uit de verschillende relevante onderwijswetten luidt nu nog als volgt (en dateert van 2006):

'Het onderwijs:

gaat er mede van uit dat leerlingen opgroeien in een pluriforme samenleving,

is mede gericht op het bevorderen van actief burgerschap en sociale integratie, en

is er mede op gericht dat leerlingen kennis hebben van en kennismaken met verschillende achtergronden en culturen van leeftijdgenoten.' 
te bieden aan mogelijk subversieve opvattingen, blijkens de memorie van toelichting. ${ }^{4}$ Van belang is ook onder ogen te zien dat elk kind leerplichtig is, zodat met dit wetsvoorstel beoogd wordt elk kind dat zich in Nederland bevindt het respect voor de basiswaarden van de democratische rechtsstaat bij te brengen.

In dit artikel wil ik allereerst de beoogde wettelijke burgerschapsopdracht van twee kanten in een breder perspectief plaatsen. In paragraaf 1 met een schets van de kennelijke zoektocht in het publiek debat naar een nadere definiëring en handhaving van democratische c.q. nationale kernwaarden. Dit om na te gaan en te evalueren welke waarden in het publiek debat essentieel worden geacht voor de democratische rechtsstaat. Voor het tweede perspectief ga ik in paragraaf 2 in op het meest recente debat over de vrijheid van onderwijs. Hierover liet de Onderwijsraad in december 2019 diverse publicaties het licht zien: de notitie Onderwijsvrijheid én overheidszorg en vier essays van externe auteurs. Dit om de voorgestelde burgerschapsbepaling te evalueren in het licht van de grondwettelijke onderwijsvrijheid. Gelet op de recente debatten zou het immers wat kortzichtig zijn om die evaluatie louter juridisch aan de hand van het nu geldend recht uit te voeren, zodat ik de onderwijsvrijheid benader vanuit de vraag in welk opzicht deze in de huidige tijd van belang is. Het blijkt namelijk dat niet alleen pleitbezorgers van inperking van de onderwijsvrijheid zich beroepen op de wenselijkheid van meer overheidsbemoeienis met burgerschapsvorming. Juist ook voorstanders van een onverminderde bescherming van de Nederlandse onderwijsvrijheid beroepen zich op het belang van goede burgerschapsvorming.

In de derde paragraaf formuleer ik op basis van deze beide perspectieven een mogelijke bepaling voor de burgerschapsopdracht. Daarna komt het wetsvoorstel aan de orde, waarbij ik ook de memorie van toelichting betrek en mij voor de focus van dit artikel beperk tot de wijze waarop de basiswaarden van de democratische rechtsstaat worden aangeduid en afgebakend.

\section{$1 \quad$ Naar nationale kernwaarden?}

De tijd van nu kenmerkt zich enerzijds door een pluraliteit aan levensbeschouwingen, en anderzijds door een relatieve homogeniteit van de meerderheid in levensbeschouwelijk opzicht. In het tijdperk van de verzuiling waren er vooral minderheden, die echter na de ontzuiling grotendeels lijken te zijn opgegaan in een liberale cultuur. Daarbij laten de laatste twee decennia een steeds breder gedeeld streven zien naar het bewaren en handhaven van Nederlandse waarden. Ten opzichte van het einde van de vorige eeuw is er onmiskenbaar een sterkere behoefte aan handhaving van een bepaalde publieke moraal; het waarderelativisme heeft aan draagvlak ingeboet in de publieke opinie. De nadruk op moreel individualisme heeft plaatsgemaakt voor nadruk op een gezamenlijke liberale ethiek, waarin individueel gelijke kansen nog steeds belangrijk zijn, maar vooral 
ook een vorm van breed gedeeld burgerschap ${ }^{5}$ waaraan Nederlanders zich moeten committeren. Breed gedeelde waarden en normen worden belangrijk gevonden. Ernst van den Hemel omschreef dit jongste cultuurverschijnsel treffend als 'postseculier nationalisme', heel beknopt door hemzelf samengevat als volgt: ${ }^{6}$

'(...) die vorm van politiek bedrijven die een verwevenheid van seculiere waarden en religieus culturele kaders als basis neemt voor het formuleren van en op de bres springen voor een bedreigde culturele nationale identiteit die verdedigd moet worden tegen andere culturen die als inherent incompatibel met de eigen cultuur gezien worden.'

Postseculariteit wordt door Van den Hemel bij zowel progressieve auteurs als bij meer conservatieve politieke figuren gesignaleerd en komt er kort gezegd op neer dat religie niet meer wordt geacht voortdurend in betekenis te zullen afnemen in de westerse samenleving; er is dus sprake van een herwaardering van religie, ook voor de publieke ruimte, hoewel het geïnstitutionaliseerde karakter van religie niet meer vanzelfsprekend is. Maar de veronderstelling dat de staat seculiere principes moet hanteren omdat religie primair iets is voor de privésituatie, verliest draagvlak omdat dit seculiere principe niet neutraal genoemd kan worden. Bovendien, de religieuze aspecten van de cultuur worden ook in de publieke ruimte expliciet van belang geacht, zoals ook Matthias Smalbrugge betoogt. ${ }^{7}$ Overigens - als belangrijke nuancering op de tegenstelling die Smalbrugge lijkt te constateren tussen deze erkenning en de publieke plaats van religie in de afgelopen twee eeuwen - is voor de Nederlandse verhouding tussen overheid en religie ook gedurende de twintigste eeuw wel kenmerkend geweest dat de overheid voor publieke belangen gewoon samenwerkte met allerlei levensbeschouwelijke organisaties. $^{8}$

Het aspect 'nationalisme' is in de analyse van Van den Hemel vooral kenmerkend voor de (min of meer) conservatieve publicisten en politici, in navolging van Frits Bolkestein en Pim Fortuyn. Zij appelleren aan een bepaald nationaal Nederlands identiteitsbesef, mede met verwijzing naar de christelijk-religieuze wortels van de Nederlandse cultuur.

$\mathrm{Nu}$ is er over een dergelijke Nederlandse identiteit diepgaand debat met hen die ik grofmazig als '21ste-eeuwse multiculturalisten' aanduid: zij die zich verzetten tegen een definitie van de Nederlandse identiteit waarin met name moslims casu quo Nederlanders met een achtergrond uit oostelijke of zuidelijke culturen zich

5 Opvallend is dat de term 'burgerschap' nu veelal verbonden wordt aan het delen van democratische kernwaarden, waar het begrip 'burgerschap' in de literatuur in de jaren negentig ook veelbesproken is, maar dan meer in de betekenis van actieve betrokkenheid, verantwoordelijkheidsbesef.

6 E. van den Hemel, “Hoezo christelijke waarden?" Postseculier nationalisme en uitdagingen voor beleid en overheid', Tijdschrift voor Religie, Recht en Beleid 2017, 2, p. 5-23.

7 M. Smalbrugge, 'Christelijke identiteit als cultureel gegeven in Nederland', Tijdschrift voor Religie, Recht en Beleid 2019, 1, p. 8-25.

8 Zie hierover J. van den Brink, 'Subsidie aan levensbeschouwelijke organisaties is ook van deze tijd', Nederlands Juristenblad 2019/39, p. 2951-2954, en de daar genoemde literatuur. 
niet herkennen, maar vaak ook nadrukkelijk bepaalde morele standpunten vanuit een liberalisme van individuele zelfbepaling uitdragen, als een soort 'grens aan het multiculturalisme'. Ik denk dan aan het geluid van partijen als D66 en de PvdA onder leiding van Asscher. Opvallend aan dit 'laat-liberalisme' (zoals HansMartien ten Napel dit aanduidt ${ }^{9}$ ) in Nederland is dat ook daarmee een zeker nationalisme verbonden lijkt te zijn, doordat de individualistisch-liberale waarden worden verheven tot basiswaarden voor de Nederlandse samenleving die alle Nederlanders, meer of minder religieus, zouden moeten onderschrijven.

Dit laat-liberalisme kan verbonden worden met wat de liberale filosoof William A. Galston heeft aangeduid als autonomy liberalism. Het gaat dan om het vertrekpunt dat elk individu zo veel mogelijk eigen keuzevrijheid zou moeten hebben. Dat sluit op zichzelf dus aan bij morele opvattingen die door de grote meerderheid wel gedeeld worden, maar waar het bij deze autonomieliberalen om gaat is dat de staat ook een taak heeft in het corrigeren van (religieuze) maatschappelijke verbanden waarbinnen deze individuele autonomie niet als ideaal geldt of niet als ultiem ideaal. Ondertussen is ook duidelijk dat dit autonomie-uitgangspunt een belangrijke levensbeschouwelijke keuze veronderstelt, namelijk dat 'het goede leven' een individueel zelfgekozen leven is. ${ }^{10}$

Daarmee onderscheidt het zich van het klassieke liberalisme, dat vooral een politieke filosofie betreft en de burgers en maatschappelijke verbanden en initiatieven waar mogelijk vrijwaart van staatsinmenging in interne aangelegenheden (met name op ethisch of levensbeschouwelijk terrein). ${ }^{11}$ Als het autonomieliberalisme een omvattende levensbeschouwing behelst, zouden ook autonomieliberalen in politiek en recht deze grenzen van het staatsoptreden in acht moeten nemen om te voorkomen dat vanuit een individualistische levensbeschouwing van overheidswege wordt getornd aan vrijheden van andere religies. Bovendien zouden autonomieliberalen ervoor moeten waken om dit omvattend ideaal te beschouwen als Nederlandse basiswaarden en de inhoud van een vorm van civiele religie.

De oriëntatie op de vraag wat essentieel is voor (de duurzaamheid van) de Nederlandse samenleving uit zich ook in een toenemende aandacht voor de vraag hoe deze samenleving weerbaar te maken tegen (onverhoopte) ondermijnende krachten. Een van de concrete verschijnselen daarvan is het hier besproken wetsvoorstel. Een andere uitingsvorm betreft het Wetsvoorstel tot wijziging van de

9 H.-M. ten Napel, 'Constitutioneel patriottisme ja, civiele religie nee', in: F. van den Heuvel \& P. Overeem (red.), Een vitale rechtsstaat. Grondslag, kwetsbaarheid, weerbaarheid, Nijmegen 2019, p. 35-43.

10 W.A. Galston, Liberal Pluralism. The Implications of Value Pluralism for Political Theory and Practice, Cambridge 2002; W.A. Galston, The Practice of Liberal Pluralism, Cambridge 2005; zie ook J. van den Brink, 'Staat, kerk en individuele gelovige, strijd om de dominantie', Tijdschrift voor Religie, Recht en Beleid 2015, 1, p. 95-110 en de daar genoemde literatuur.

11 Galston 2002; F. Mansvelt Beck, 'Franse toestanden?', Tijdschrift voor Religie, Recht en Beleid 2016, 3, p. 6-23. 
Grondwet. Ook is er aandacht voor de juridische instrumenten voor een 'weerbare democratie'; zie bijvoorbeeld het proefschrift van Bastiaan Rijpkema. ${ }^{12}$

\section{Proeve van een waardekader}

In de aanloop naar een reflectie op het Wetsvoorstel burgerschapsopdracht, en tegen de achtergrond van de hiervoor geschetste ontwikkelingen, ga ik hier in op de volgende vraag: als het inderdaad in de huidige tijd zinvol is om het waardekader te expliciteren, welke waarden zouden we willen identificeren als dragend voor onze democratische rechtsstaat? De veronderstelling dat het zinvol is om dergelijke waarden te benoemen, is wat mij betreft ook wel plausibel. Alleen al de onderlinge vervreemding die lijkt op te treden in het publieke debat over integratie van niet-westerse minderheden wijst op de behoefte aan overbruggende gedeelde waarden. Temeer nu met name op dit punt de 'populisten' en de 'elite' elkaar lijken te zijn kwijtgeraakt in waardering van de Nederlandse cultuur en/of de invulling of handhaving van de kernwaarden van de Nederlandse democratische rechtsstaat.

Alleen juridische begrippen schieten tekort: het gaat om de morele waarden die de juridische normen noodzakelijkerwijs inkleuren. Graag geef ik in dit verband een proeve van een beknopte publieke waardecatalogus waarvan ik intuïtief zou menen dat het delen van deze waarden essentieel is voor het kunnen leveren van een positieve bijdrage aan de hedendaagse democratische rechtsstaat. Het voert te ver om deze catalogus in deze bijdrage nader te onderbouwen; het gaat hier slechts om een vingeroefening ten behoeve van de gedachtevorming over het Wetsvoorstel burgerschapsvorming:

- Tolerantie: er is ruimte voor de diversiteit aan levensbeschouwingen om aanwezig te zijn en zich te uiten.

- Menselijke waardigheid: een menswaardig bestaan wordt iedereen gegund en ieders persoonlijkheid wordt serieus genomen, ook met gelijkheid voor de wet zonder discriminatie.

- Geweldsmonopolie bij de staat: door burgers worden (ook voor politieke doeleinden) uitsluitend vreedzame methoden gehanteerd.

- Democratie: de staat is van ons allemaal en daarom zijn we met elkaar verantwoordelijk en verdelen we de inspraak evenredig.

- Samenleven: dit betekent dat we elkaar nodig hebben in allerlei verbanden.

\section{Een voedingsbodem}

Hoewel bijna iedereen wel enigszins met elk van deze waarden uit de voeten kan, veronderstel ik toch dat zij op zichzelf onvoldoende zijn als dragend democra-

12 B. Rijpkema, Weerbare democratie. De grenzen van democratische tolerantie (diss. Leiden), Amsterdam 2015. Mij viel op dat in de notitie van de Onderwijsraad naar deze studie in een voetnoot werd verwezen, in het kader van het algemeen bespreken van de mogelijkheden in het onderwijsrecht om de democratische rechtsstaat te versterken. Nu heeft een eventueel wettelijk instrumentarium rondom politieke partijen in het kader van een weerbare democratie niet in directe zin iets te maken met een burgerschapsopdracht in het onderwijs (en is zowel de rechtsstatelijke mogelijkheid als de juridische uitwerking heel verschillend van aard), maar blijkbaar zagen ook de auteurs van deze notitie de parallel die ikin het vorenstaande trek. 
tisch-rechtsstatelijk fundament. Van belang is namelijk een bredere en dieper gewortelde inbedding in de meeromvattende levensfilosofie van burgers. De hiervoor genoemde waarden zijn expliciet geformuleerd als publieke waarden, die geen specifieke levensbeschouwelijke achtergrond veronderstellen. Een levensbeschouwelijke inbedding is echter wel gewenst, om drie redenen. Allereerst vraagt de democratische rechtsstaat van zowel burgers als bestuurders een zeker ethos, en dus een persoonlijke motivatie. Een democratie is niet duurzaam zonder dat burgers zich betrokken weten bij het algemeen belang en een besef van hun verantwoordelijkheid hebben om daaraan hun steentje bij te dragen. Daarnaast zijn er uitdagers van de democratische rechtsstaat, waarvan het bekendste voorbeeld wordt gevormd door islamitisch radicalisme in zoverre daarbinnen een repressief islamitisch regime wordt aangeprezen voor Nederland, of geweld tegen de Nederlandse samenleving. Los van de vraag hoe significant een dergelijke stroming in getalsmatig of organisatorisch opzicht is, vraagt de enkele aanwezigheid daarvan om een weerwoord in de vorm van een levensbeschouwelijk en cultureel fundament van de rechtsstaat. Zo niet om twijfelaars te overtuigen, dan wel om te tonen een ten minste gelijkwaardig alternatief te zijn voor radicalisme voor wat betreft de mogelijkheid om de rechtsstatelijke waarden ook in geloofsovertuigingen te verankeren. Ten slotte, lege tolerantie ${ }^{13}$ loopt het gevaar te verkeren in hele dunne tolerantie. Als we niet precies weten waarom die genoemde waarden eigenlijk zo belangrijk zijn en waarom de democratische rechtsstaat vanuit die waarden moet worden onderhouden, wordt de toepassing van een dergelijke waardecatalogus legalistisch, kunnen we de grenzen in concreto moeilijker afbakenen en gaan we krampachtig om met alles wat enigszins afwijkt. Bij het geven van commentaar of zelfs een politiek of juridisch antwoord op maatschappelijke (rand)verschijnselen moeten we zo'n waardekader - bestaand uit heel open begrippen - voortdurend interpreteren en hiervoor moet worden teruggegrepen op een meeromvattende culturele en levensbeschouwelijke voedingsbodem.

Waarin zoeken we dan deze voedingsbodem? Daarop zijn verschillende antwoorden mogelijk. Bijvoorbeeld in de joods-christelijke traditie, in allerlei varianten. Of in de joods-christelijk-humanistische traditie, in nog meer varianten. Of alleen de seculier-humanistische traditie waarvoor bijvoorbeeld Paul Cliteur zich sterk maakt. Of in de gereformeerde traditie. Of, zoals Lotfi El Hamidi betoogt in zijn essay voor de Onderwijsraad: dat kan ook in de islamitische traditie. ${ }^{14}$

Hiervoor signaleerde ik overigens dat er wel een levensbeschouwelijke mainstream aanwezig lijkt te zijn die liberale waarden aanhangt vanuit een persoonlijk niet-religieuze visie, maar toch lijkt er behoefte aan extra (religieus) houvast, gelet op bijvoorbeeld de toenemend voorkomende verwijzing naar de joods-christelijke wortels. Maar ook zou je die behoefte kunnen ontwaren bij de genoemde pleidooien voor het hanteren van het autonomieliberalisme als nationaal ideaal.

14 L. El Hamidi, 'Ruis in het debat over artikel 23', essay Onderwijsraad december 2019. 
Hans-Martien ten Napel signaleert de paradox dat er enerzijds een civiele religie gevraagd lijkt te worden om de democratische rechtsstaat te kunnen verankeren in gezamenlijk gedeelde meeromvattende waarden, maar tegelijkertijd zijn er groeperingen rond religieuze tradities die te uitgesproken rechtzinnig zijn om een civiele religie te kunnen delen, maar niettemin vanuit hun perspectief intrinsiek gemotiveerd bijdragen aan het vormgeven van de democratische rechtsstaat. Diezelfde rechtsstaat zou dus 'zijn wortels doorsnijden' bij het beperken van de morele ruimte voor deze tradities vanwege een vereiste 'civiele religie'. ${ }^{15}$ Bovendien zou dit betekenen dat een 'rechtsstaat' dan veel verder ingrijpt in het maatschappelijk (geestelijk) leven dan het mandaat reikt.

Het alternatief voor een civiele religie is dan het vertrouwen dat burgers en groeperingen rond verschillende tradities vanuit hun eigen perspectief de genoemde rechtsstatelijke waarden (in grote lijnen) verankeren en vormgeven. De doorwerking daarvan in het politieke debat houdt dit debat natuurlijk spannend, maar behoeft dit debat niet onmogelijk te maken, temeer niet wanneer men de suggestie vermijdt neutraal te zijn en daarom meer recht van spreken te hebben. Met het vorenstaand pleidooi zeg ik dus niets over de eventuele wenselijkheid van bijvoorbeeld het aanhouden van de christelijke cultuur als leidraad voor publiek beleid. Als dit 'publiek beleid' maar tijdig halt houdt en de burgers de ruimte laat in hun persoonlijk en organisatorisch leven (ook in het onderwijs).

Een discussie over waarden die wezenlijk zijn voor de democratische rechtsstaat is vanzelfsprekend relevant in allerlei opzichten. Ze kan ook dienen als inspiratiebron bij een meer concreet debat over juridische toepassingen in bijvoorbeeld voorschriften over burgerschapsonderwijs. Maar het besef dat juridische toepassingen naar hun aard harde grenzen trekken, en dat dit noopt tot ruime behoedzaamheidsmarges, is dan wel cruciaal. Immers, zo'n met goed-rechtsstatelijke bedoelingen getrokken grens schiet zijn doel voorbij wanneer overtuigen onnodig daarbuiten worden gesloten.

\section{Vrijheid van onderwijs: ontwikkelingen, opvattingen en commentaar}

De onderwijsvrijheid stelt grenzen aan wat de overheid inhoudelijk aan onderwijsinstellingen kan voorschrijven in het kader van burgerschapsonderwijs. De Grondwet plaatst zowel onderwijsvrijheid als overheidszorg naast elkaar; die overheidszorg is echter niet bedoeld om de overheid instrumenten voor sociaal beleid aan te reiken, maar om goed onderwijs te waarborgen. Vanouds geldt de richtingsvrijheid als het meest wezenlijke aspect van de onderwijsvrijheid: het betreft de invulling van de levensbeschouwelijke grondslag en daarmee de ruimte voor ouders en schoolbesturen om de diepste drijfveren voor hun kinderen te laten vormen. Het vloeit daarmee voort uit de collectieve dimensie van de vrijheid van godsdienst. Deze fundamentele vrijheid vormde in 1917 reden tot invoering van het duaal stelsel. Daarbij was van belang dat de eisen aan onderwijsinstellingen van dien aard werden dat voor het overgrote deel van de bevolking particulier 
onderwijs onmogelijk is. Daarnaast werd het als onrechtvaardig beschouwd wanneer ouders via het belastinggeld alleen zouden bijdragen aan openbaar onderwijs en hun richtingsonderwijs daarnaast zelf moesten dragen. In de tweede helft van de negentiende eeuw was ook de overtuiging gegroeid dat een streven naar levensbeschouwelijk neutraal onderwijs ook niet waardevrij kan zijn en onvermijdelijk levensbeschouwelijke keuzes vergt - waarmee die neutraliteit dus niet een veel sterker bestaansrecht legitimeerde. ${ }^{16}$

\section{Bezwaren}

Maar er zijn recent ook meer fundamentele bezwaren ingebracht tegen de richtingsvrijheid die rechtstreeks verband houden met de hiervoor al aangeduide culturele ontwikkelingen.

Tegen de richtingsvrijheid worden recent met name de volgende bezwaren ingebracht. Daarvoor verwijs ik naar het position paper van VOS/ABB. ${ }^{17}$ Diens bezwaar luidt dat de aanwezigheid van scholen van en voor een bepaalde religieuze bevolkingsgroep haaks zou staan op de waarde van gelijke kansen voor iedereen. Blijkbaar zijn we zodanig gewend geraakt aan een levensbeschouwelijke homogeniteit in de meerderheid van de samenleving, dat we 'samenscholing' van religieuze bevolkingsgroepen met achterdocht benaderen. Bovendien is er een sterker verlangen (dan in de eerste decennia van de ontzuiling) naar gedeelde waarden. In die omstandigheden slaat kennelijk bij sommigen de twijfel toe of deze samenscholing niet nadelig is in het streven naar een breed gedeelde burgerschapsethiek te midden van religieus pluralisme.

Daarbij spelen mogelijk twee twijfels een rol. Allereerst de vraag of deze 'samenscholing' er niet toe leidt dat kinderen te weinig van dichtbij kennismaken met andere identiteiten. Mij dunkt dat deze zorg ongefundeerd is: juist in de hedendaagse samenleving, die door internet en social media opener is dan ooit tevoren, is niet voorstelbaar dat 'samenscholing' binnen richtingsscholen zou kunnen leiden tot 'parallelle samenlevingen'. Met name de door de grote meerderheid aangehangen visies kan ook kinderen van 'minderheidsscholen' niet ontgaan.

De zorg om 'samenscholing' lijkt vooral de opvatting te weerspiegelen dat alle kinderen in Nederland de waarde van inclusiviteit moet worden bijgebracht door middel van kleurrijke scholen. Echter, die opvatting (met name over de rol van het onderwijs) wordt lang niet door alle Nederlanders gedeeld en kan niet als uitgangspunt voor wetgeving dienen - onder andere vanwege de ingrijpende consequenties die dat zou hebben voor ouders die hun kinderen uit overtuiging naar richtingsscholen brengen. Het betoog voor een dergelijk instrumenteel onderwijsbeleid doet mij denken aan de nationale-eenheidspolitiek onder koning Willem $\mathrm{I} ;{ }^{18}$ het inzetten van onderwijsbeleid voor een moreel geladen eenheidsstreven

17 'De vrijheid van onderwijs is dood... Leve de vrijheid van onderwijs. Position paper: artikel 23 Grondwet', gepubliceerd in 2019 door VOS/ABB, te vinden op www.vosabb.nl/artikel-23-allescholen-algemeen-toegankelijk/.

18 Zie daarvoor bijv. I. de Haan, 'Een gevelde Goliath? Liberale onderwijspolitiek 1848-1920', in: Van der Ploeg e.a. (red.), De vrijheid van onderwijs, Utrecht 2000, p. 35-57. 
kan potentieel repressieve trekken krijgen, dus die neiging dienen we in onze huidige rechtsstaat te onderdrukken.

In haar essay voor de Onderwijsraad formuleert Stine Jensen haar fundamentele bezwaar tegen de richtingsvrijheid in het onderwijs als volgt: ${ }^{19}$

'Religieuze intolerantie en geloofsoverdracht behoren voor mij niet tot de taken van een school, maar als het gaat om algemeen bijzonder onderwijs het aanbod van verschillende onderwijsconcepten, dan zou ik daar voor zeker pleiten. Met andere woorden: schaf die vrijheid van richting, de vrijheid van het bijzonder onderwijs om een bepaalde overtuiging ontleend aan een specifieke godsdienst af, maar behoud de vrijheid van inrichting of wel de pedagogische autonomie van scholen, de vrijheid om zelf een onderwijskundig concept, een pedagogisch-didactische aanpak te kiezen.'

Ik meen echter dat hier een belangrijke denkfout schuilt: als de staat niet geïnteresseerd is in de godsdienstige opvattingen van burgers, dan is dat immers geen reden om de richtingsvrijheid af te schaffen. Temeer niet wanneer wel wordt geconstateerd dat er verschillende opvattingen bestaan en dat die voor burgers belangrijk zijn - ook voor het onderwijs.

Daarnaast lijkt Jensen te veronderstellen dat het onderwijs neutraal zou moeten zijn en bovendien dat dit gelijk staat aan seculier. Het is precies die veronderstelling die door Rosanne Hertzberger in haar essay in allerlei bewoordingen wordt afgewezen: ook seculier liberalisme (in welke vorm dan ook) stoelt op een bepaalde levensbeschouwing en is daarmee niet neutraal. ${ }^{20}$ Ook in andere literatuur is uitvoerig betoogd dat het onmogelijk is om morele en levensbeschouwelijke neutraliteit in het onderwijs na te streven. ${ }^{21}$

\section{Redenen voor onverminderde bescherming}

Tegenover de hiervoor besproken kritiek op de richtingsvrijheid in het onderwijs zijn er wat mij betreft belangrijke redenen om deze onverkort te beschermen.

In de zoektocht naar gemeenschapszin die onze tijd kenmerkt, schuilt de terechte overtuiging dat de mens als individu niet autonoom op eigen benen kan staan: we hebben gemeenschappen om ons heen nodig, juist ook voor zingeving en voor morele reflectie. ${ }^{22}$ Een dergelijke rol als vormende gemeenschap zouden we toch echter niet bij de staat willen beleggen. Daartoe zijn er de gemeenschappen die wij zelf, autonoom, regelen, zoals gezin, familie, school, club, kerk enzovoort.

19 Essay S. Jensen, Onderwijsraad december 2019.

20 R. Hertzberger, 'Vrijheid van onderwijs: het recht op je eigen bubbel', essay Onderwijsraad december 2019.

21 Zie bijv. A. Gutmann, Democratic Education, Princeton 1987; Ch.L. Glenn, 'Does the Dutch Education Model Still Make Sense’? essay Onderwijsraad, december 2019; Ch.L. Glenn, 'Structural Pluralism in Education: Can We Stop Fighting over Schools?', Johns Hopkins Institute for Education Policy 2017, https://edpolicy.education.jhu.edu/structural-pluralism-in-education-can-we-stopfighting-over-schools/.

22 H.-M. ten Napel, Constitutionalism, Democracy and Religious Freedom. To Be Fully Human, Londen 2017. 
In allerlei tradities, ook binnen het liberalisme, wordt om die reden het belang benadrukt (zeker in een pluriforme maatschappij) dat er een diversiteit aan verbanden kan bestaan (divers zowel qua vorm als qua identiteit), die de staat (met een eigen en afgebakende taak in de samenleving) niet als verlengstuk kan beschouwen. ${ }^{23}$ Als het waar is dat het onderwijs niet zozeer de staat of de samenleving dient, maar de kinderen moet voorbereiden op een plaats daarin, moeten we het onderwijs ook niet beschouwen als staatsinstrument voor het bevorderen van sociale cohesie, van loyaal burgerschap of van het opvoeden naar nationale waarden. Juist in een tijd waarin er enerzijds een behoefte bestaat aan een breed gedeelde burgerschapsethiek, maar er anderzijds consensus ontbreekt over de exacte reikwijdte van deze waarden en ook over de levensbeschouwelijke inkleuring, moeten we het risico onder ogen zien dat overheidsinstrumenten te ver gaan in het inperken van maatschappelijke vrijheden. Essentieel voor de rechtsstaat is immers dat de staat zijn burgers en organisaties vrij laat in het geloven in levensbeschouwelijke of religieuze waarden. Dit rechtsstatelijk beginsel staat op zichzelf niet ter discussie, maar betekent ook dat we een eventuele neiging moeten onderdrukken om via het onderwijsbeleid van staatswege inhoudelijke invloed uit te oefenen op het waardekader van (aankomende) burgers. We zouden niet gebaat zijn bij onderwijsinstellingen die 'een lesje uit de wet' afdraaien, maar bij instellingen waarin positief-kritisch wordt gereflecteerd op politieke ontwikkelingen. Het maatschappelijk debat behoort niet door overheidssturing te worden gehinderd, zeker niet waar dat binnen scholen plaatsvindt.

De zogenoemde civil society is in een democratische rechtsstaat van grote waarde om de nodige checks and balances in stand te houden, zodat de staat de grenzen van zijn autoriteit niet overschrijdt en ervoor waakt om de samenleving in al haar geledingen naar zijn hand te willen zetten. ${ }^{24} \mathrm{Nu}$ is de onderwijsbranche in Nederland een van de belangrijkste terreinen waar florerende organisaties actief zijn en ook om die reden moet de staat opletten dat die organisaties geen verlengstuk worden. Maar dan is ook cruciaal dat deze organisaties hun eigen morele kader ontwikkelen - zonder dat de staat alles wat kritisch is aan de zijlijn plaatst.

De tweede reden voor het onverkort vasthouden aan de richtingsvrijheid is het onverminderd belang van levensbeschouwelijke vorming in het onderwijs. Richtingsscholen voorzien in een behoefte wanneer zij niet louter lesstof overdragen (bijvoorbeeld over de Grondwet), maar ook inleiden in inspiratiebronnen, tradities, zingeving en levensbeschouwing. De waarden die we willen overdragen (met welke vreedzame invulling dan ook precies) moeten immers geen laagje vernis worden, maar zo mogelijk verankerd worden in gewetens- en levensbeschouwingen. ${ }^{25}$ Democratie veronderstelt betrokkenheid van zo veel mogelijk burgers en instellingen bij wetgeving en bestuur. Richtingsscholen dragen bij aan

25 H.E.S. Woldring, 'Bijzonder onderwijs en de sociale cohesie in de samenleving', in: Van der Ploeg e.a. (red.), De vrijheid van onderwijs, Utrecht 2000, p. 231-242. 
een gespecificeerd intrinsiek draagvlak voor de democratische rechtsstaat vanuit allerlei denominaties. ${ }^{26}$

De Amerikaanse emeritus hoogleraar Charles Glenn, die veel onderzoek heeft verricht naar onderwijsstelsels in Europa en de Verenigde Staten, heeft herhaaldelijk betoogd dat scholen met een duidelijke levensbeschouwelijke identiteit bij uitstek in staat zijn goed onderwijs te bieden, ook goed burgerschapsonderwijs. Dit omdat het onderwijs en de vorming kunnen worden ingebed in een consistent mens- en wereldbeeld. Hij maakt onderscheid tussen instruction (het aanleren van kennis en vaardigheden) en education ('shape the character, values, life goals, and loyalties of their students'). ${ }^{27}$ Education in deze zin veronderstelt dat school als een moral community kan worden gezien, maar zoals uit allerlei onderzoeken blijkt geeft het wel de beste resultaten, juist ook van burgerschapsonderwijs. ${ }^{28}$ Loyale burgers worden verkregen "by drawing upon the Dutch tradition of empowering civil society institutions to serve common societal goals (...). This requires confronting the common but mistaken assumption that national and social unity require cultural uniformity. ${ }^{29}$

Maar ook vanuit het kindperspectief is het veiliger wanneer kinderen naar school kunnen in een omgeving die qua waardeopvoeding en levensovertuiging aansluit bij de thuissituatie. ${ }^{30}$ In die veilige situatie gedijt de ontwikkeling het beste, en zoals gezegd is er naast school in de huidige open samenleving voldoende mogelijkheid om in aanraking te komen met andere overtuigingen en leefwijzen.

\section{Naar een verantwoorde burgerschapsopdracht}

Hoe zou een wettelijke burgerschapsopdracht eruit kunnen zien, als we de hiervoor geschetste lijnen in het oog houden? Samengevat: er zijn wel onderliggende algemene waarden van onze democratische rechtsstaat te formuleren, maar ook is verankering in intrinsieke drijfveren van de burgers van belang. Een nationale civiele religie is daarvoor niet wenselijk maar ook niet nodig, omdat de verschillende eigen tradities en levensbeschouwingen van burgers een meer effectieve

Glenn 2017; G.D. Bertram-Troost, 'Refoscholen op de balk: balanceren tussen eigenheid en openheid', in: J. Exalto (red.), De multiculturele refoschool. Het reformatorisch onderwijs en de uitdaging van het pluralisme, p. 23-56; M. Beemsterboer, 'Islamitische scholen dragen bij aan integratie', Tijdschrift voor Religie, Recht en Beleid 2019, 1, p. 26-36. Deze overweging wordt ook benoemd door S. Philipsen, 'Meer ruimte voor nieuwe scholen?', Tijdschrift voor Religie, Recht en Beleid 2018, 1, p. 62-75. Tegelijkertijd betoogt hij dat 'te veel onderwijsvrijheid' segregatie in de hand kan werken. Op dit punt kan volgens hem een burgerschapsopdracht aan scholen soelaas bieden, waarbij hij ook de haken en ogen van een sterk inhoudelijk sturende opdracht opmerkt. In dit artikel bedoel ik met mijn betoog aan te geven dat het inderdaad weinig zinvol is om krampachtig te proberen als overheid met inhoudelijke wetgeving zo veel mogelijk integratie rond de basiswaarden te bevorderen, en dat er juist weinig reden is om te vrezen voor 'parallelle samenlevingen' wanneer groeperingen rond levensbeschouwelijke uitgangspunten een specifieke, intrinsieke motivatie overdragen voor verantwoord burgerschap.

30 J. de Jong, Waardenopvoeding en Onderwijsvrijheid (diss.), Nijmegen 1998. 
verankering bieden. Het is deze overweging die ook belangrijke en actuele redenen in zich heeft om de richtingsvrijheid in het onderwijs te blijven beschermen. Juist op die wijze kunnen aankomende burgers worden gevormd die intrinsiek gemotiveerd zijn voor hun burgerschap.

Alvorens dit te vertalen in een wettelijke burgerschapsopdracht aan het onderwijs, waarbij dus waarden worden aangeduid die in het onderwijs positieve aandacht moeten krijgen, moet duidelijk zijn wat met deze wettelijke opdracht wordt beoogd. ${ }^{31}$ Het doel van de huidige wetgever lijkt tweeledig. Allereerst is het de bedoeling een verplichting in het leven te roepen om 'op een doelgerichte en samenhangende wijze' aandacht te besteden aan burgerschapsvorming in het onderwijs, zodat het democratisch verantwoordelijkheidsbesef zo veel mogelijk wordt gewaarborgd bij de aankomende burgers. Zoals hiervoor al gesignaleerd wordt in dit wetsvoorstel, veel meer dan in de burgerschapsliteratuur uit het eind van de vorige eeuw, voor dit verantwoordelijkheidsbesef vooral veel waarde gehecht aan het inhoudelijk delen van 'basiswaarden'. Daarnaast - en dit sluit nog meer rechtstreeks aan bij de prominente positie van de inhoudelijke basiswaarden - is het de bedoeling om te voorkomen dat op scholen antidemocratisch gedachtegoed wordt gefaciliteerd. ${ }^{32}$

Een bepaling die aan deze doelstelling moet beantwoorden, zou als volgt kunnen luiden:

Het onderwijs bevordert actief burgerschap en sociale cohesie op doelgerichte en samenhangende wijze.

In het onderwijs worden geen opvattingen verdedigd waarin het gebruik van niet-gelegitimeerd geweld wordt aanvaard, waarin het uitoefenen van geweld tegen mensen met een ander geloof of levensovertuiging wordt aanvaard of waarin wordt aangezet tot haat of respectloze discriminatie van mensen, zoals bedoeld in het Wetboek van Strafrecht. ${ }^{33}$

31 Zie ook het overzichtsartikel van M. Sundström \& Ch. Fernández, 'Citizenship Education and Diversity in Liberal Societies: Theory and Policy in a Comparative Perspective', Education, Citizenship and Social Justice, 2013, 2, p. 103-117.

32 De Onderwijsraad behandelt in zijn notitie Onderwijsvrijheid én overheidszorg de burgerschapsopdracht onder de noemer 'onderwijskwaliteit'. Dat is op zichzelf een interessant perspectief, dat tot uitdrukking brengt dat deze opdracht vooral een regeling is voor de 'inrichting' van het onderwijs en componenten van kennis en vaardigheden voorschrijft. Evenwel is de strekking van mijn artikel dat het bij de burgerschapsopdracht (ook naar de bedoeling van de wetgever) om méér gaat: namelijk ook het voorschrijven van een zekere inhoudelijke waardering van 'basiswaarden'.

33 De toegevoegde waarde van het introduceren van dit discriminatieverbod uit het strafrecht in de onderwijswetten is daarin gelegen dat dit verbod daardoor voor de onderwijsinstelling gaat fungeren als een bekostigingsvoorwaarde. Zo overweegt ook de minister in de MvT, waar eveneens mede bij de strafbepaling wordt aangesloten ter toelichting op de 'basiswaarden'. 


\section{Bespreking van het voorliggend voorstel}

De door het kabinet nu voorgestelde nieuwe burgerschapsopdracht luidt als volgt: ${ }^{34}$

'Artikel 8, derde lid, van de Wet op het primair onderwijs wordt vervangen door:

3. Het onderwijs bevordert actief burgerschap en sociale cohesie op doelgerichte en samenhangende wijze, waarbij het onderwijs zich in ieder geval herkenbaar richt op:

a het bijbrengen van respect voor en kennis van de basiswaarden van de democratische rechtsstaat, zoals verankerd in de Grondwet, en de universeel geldende fundamentele rechten en vrijheden van de mens; en

b het ontwikkelen van de sociale en maatschappelijke competenties die de leerling in staat stellen deel uit te maken van en bij te dragen aan de pluriforme, democratische Nederlandse samenleving.

3a. Het bevoegd gezag draagt zorg voor een schoolcultuur die in overeenstemming is met de waarden, bedoeld in het derde lid, onderdeel a, en creëert een omgeving waarin leerlingen worden gestimuleerd actief te oefenen met de omgang met deze waarden.'

\section{Beperking van de vrijheid van onderwijs?}

Gaat het hier nu, juridisch bezien, om een beperking van de onderwijsvrijheid? Duidelijk is dat aan scholen nu een opdracht wordt verstrekt en kaders worden gesteld die minder ruimte geven om het onderwijs in te richten en ethisch richting te geven dan hiervoor. Zo bezien is er dus onmiskenbaar sprake van een beperking.

In ons constitutioneel bestel is het aan de wetgever zelf om de grondwettigheid van nieuwe wetgeving te toetsen. Zoals verwacht bevat de memorie van toelichting $^{35}$ (MvT) dan ook een uitgebreide paragraaf (paragraaf 7) waarin een verantwoording wordt geboden van de beoogde burgerschapsopdracht in het licht van de vrijheid van onderwijs. Volgens het kabinet betreft het in feite geen beperking van de geldende richtingsvrijheid, omdat diezelfde onderwijsvrijheid reeds moet worden bezien in het licht van het geheel van de democratische rechtsstaat, en dat hieraan inherent is dat een beroep op onderwijsvrijheid altijd impliceert dat men de daaraan gekoppelde verantwoordelijkheid voor het geheel van de Grondwet waarin deze vrijheid is ingebed, ook serieus neemt. Hiermee is een elegante verantwoording gegeven: vrijheid impliceert immers altijd verantwoordelijkheid. En het enkel stellen dat de wetgever altijd de uitoefening van grondrechten zou mogen beperken, zou te gemakkelijk zijn geweest en ten onrechte de suggestie hebben gewekt dat grondrechten slechts zo ruim zijn als de ruimte die de

34 Kamerstukken II 2019/20, 35325, 2. Ik geef alleen de bepaling weer die de Wet op het primair onderwijs moet wijzigen. Het wetsvoorstel bevat gelijkluidende bepalingen voor de Wet op het voortgezet onderwijs, de Wet op de expertisecentra en de wetten voor de BES-eilanden. 
wetgever laat. De MvT stelt dus dat het wetsvoorstel enkel expliciet maakt wat in feite al impliciet aan artikel 23 Grondwet verbonden was.

\section{Inhoud van de opdracht}

Met dit laatste veronderstelt dus de indiener dat bij de toepassing en interpretatie van de nieuwe bepaling dezelfde ruimte voor het onderwijs aanwezig blijft als er gegeven is met het geheel van onze Grondwet en democratische rechtsstaat. Met andere woorden, verondersteld wordt dat de bepaling niet leidt tot minder mogelijkheden voor inhoud en vorm voor het burgerschapsonderwijs dan er al aanwezig waren voor een school die verantwoordelijkheidsbesef droeg voor de democratische rechtsstaat.

Voor dit eerbiedigen van de richtingsvrijheid bij de toepassing van deze wet dient de wet dan echter wel duidelijke waarborgen te bevatten. Ondubbelzinnig moet zijn (vanuit de wettekst zelf, omdat de wetshistorie geen bindend interpretatiekader is) dat met name de Onderwijsinspectie die ruimte voor scholen niet verder kan inperken, en dat hetzelfde geldt in voorkomende gevallen voor de minister en de rechter bij het nemen en toetsen van besluiten in het kader van de handhaving van de burgerschapsopdracht. De bepaling moet dus voor de inhoud van de opdracht aan scholen openheid en vrijheid bieden, en aan de uitvoerende en rechtsprekende macht tegelijkertijd geen ruimte laten voor een interpretatie die de beoogde vrijheid alsnog inperkt. De wetgever zou immers zijn taak binnen de Nederlandse trias politica niet verstaan wanneer de wet zodanig wordt geformuleerd dat de grondwettelijke onderwijsvrijheid in de praktijk veel verder kan worden ingeperkt dan in de constitutionele verantwoording uit de MvT wordt verondersteld.

Terecht wijst de Raad van State in zijn advies op het belang dat de wet zo veel mogelijk duidelijkheid geeft over de vraag wanneer eraan voldaan is en wanneer niet. Ook als een bepaling een open karakter heeft om onderwijsinstellingen de ruimte te bieden, moet wel vooraf helder zijn wanneer de school er niet aan voldoet. Temeer nu de bepaling een bekostigingsvoorwaarde stelt. ${ }^{36}$

Op dit punt echter schiet het wetsvoorstel fundamenteel tekort. Niet alleen gelet op de wettekst als zodanig, maar ook gelet op de ambivalente houding in de MvT, waarin mede tendensen waarneembaar zijn die suggereren dat er een specifieke ethische invulling van de 'basiswaarden' van het onderwijs wordt verwacht. Dit werk ik hierna nader uit.

Centraal staat in dit voorstel het 'bijbrengen van respect voor de basiswaarden van de democratische rechtsstaat'. Daarbij is ervoor gekozen om geen zelfstandige formulering op te nemen die de inhoud van deze basiswaarden omschrijft, maar te verwijzen naar 'de Grondwet en de universeel geldende fundamentele rechten en vrijheden van de mens'. Voordeel hiervan is dat gebruik wordt gemaakt van een 'externe autoriteit', zodat elke zweem van subjectiviteit bij het formuleren van basiswaarden wordt vermeden. Het nadeel van deze formulering 
is echter dat die subjectiviteit alsnog een rol kan spelen bij het toepassen van deze bepaling in handhavingssituaties: het kan uiteraard erg diffuus zijn wanneer sprake is van strijd met de 'universeel geldende fundamentele rechten van de mens'. De verwijzing naar de Grondwet lijkt concreter, maar biedt in feite ook niet meer houvast. Het gaat in de burgerschapsopdracht immers niet om het onverkort onderschrijven van alle nu geldende artikelen uit de Grondwet, maar ook hier gaat het om de achterliggende basiswaarden.

De MvT geeft wel enige richting aan de inhoud van deze basiswaarden. Het blijkt te gaan om het principe van 'menselijke waardigheid', waaruit de beginselen van 'vrijheid, gelijkwaardigheid en solidariteit' voortvloeien.

Opmerkelijk is vervolgens dat de consultatieversie van de MvT verder ging in het uitwerken van de basiswaarden, waar dit veel minder gebeurt in de MvT bij het thans ingediende wetsvoorstel. Het advies van de Raad van State en de consultatiereacties hebben kennelijk geleid tot een terugtreding op dit punt.

Het verschil kan geillustreerd worden aan de hand van twee citaten die zijn genomen uit de 'oude' MvT, paragraaf 5: de toelichting op de 'basiswaarden': ${ }^{37}$

'Ook moet worden gedacht aan het uitgangspunt dat iedereen aan dezelfde regels en wetten is gebonden, en aan beschermende waarden die zijn vervat in de grondrechten en mensenrechten, in het bijzonder de menselijke waardigheid, persoonlijke autonomie en het recht van elk individu om zijn eigen keuzes te maken.'

'Toegespitst op de ontwikkelingsfase voor leerlingen in het funderend onderwijs betekent dat dat scholen hun onderwijs in ieder geval herkenbaar zouden moeten richten op: de vrijheid van meningsuiting, gelijkwaardigheid, begrip voor anderen, verdraagzaamheid, autonomie, het afwijzen van onverdraagzaamheid en het afwijzen van discriminatie.'

In de 'nieuwe' MvT komt het eerste citaat niet meer voor. Het tweede citaat wordt nu voorafgegaan door de zinsnede: 'Een mogelijke manier waarop scholen de basiswaarden in hun onderwijs zouden kunnen belichten is door (...). 38

Een derde citaat uit de 'oude' MvT, uit paragraaf 7, waarin de verhouding van deze burgerschapsopdracht met de vrijheid van onderwijs wordt toegelicht, luidt: ${ }^{39}$ verduidelijking van de burgerschapsopdracht aan scholen in het funderend onderwijs, p. 12 (het eerste citaat ook op p. 21).

38 MvT, p. 13. Overigens wordt op p. 17 en 18 van de MvT nog wel deze catalogus benoemd in het kader van de voorgeschreven schoolcultuur. Het wordt er hiermee niet duidelijker noch consistenter op: zijn deze waarden nu niet meer expliciet bepalend voor de invulling van lid 3 (het onderwijs), maar nog wel voor lid 3a (de schoolcultuur)? 
'Deze grondwettelijke vrijheid is niet absoluut en dient in een bredere context van algemeen aanvaarde kernwaarden van de democratische rechtsstaat te worden bezien en daarmee ook in verhouding tot andere grondrechten. Met name het in artikel 1 Grondwet vervatte beginsel van nondiscriminatie kan leiden tot begrenzing van de vrijheid van onderwijs. Deze begrenzing van de vrijheid van richting geldt op basis van het hier geschetste kader thans reeds voor iedere school. Zo worden binnen de school discriminerende uitlatingen van bij het onderwijs betrokken personen over seksuele gerichtheid, genderidentiteit of over de positie van de vrouw onaanvaardbaar geacht. Wel mag bijvoorbeeld tijdens een les worden aangegeven dat op grond van de basiswaarden van de democratische rechtsstaat de vrijheid van meningsuiting, de vrijheid van godsdienst en de vrijheid van onderwijs belangrijk zijn, en dat je als mens daarom mag geloven en tot op zekere hoogte zeggen wat je wil, maar dat de basiswaarden tevens meebrengen dat iedereen gelijkwaardig is.'

In de 'nieuwe' versie is deze afweging anders verwoord: ${ }^{40}$

'Uit de volgorde, formulering of ouderdom van de grondrechten is geen onderlinge rangorde van grondrechten af te leiden. Het ontstaan van spanningen tussen verschillende grondrechten is tot op zekere hoogte inherent aan de aard van die grondrechten en aan het samenleven in een pluriforme, democratische samenleving. Dit verschijnsel doet zich bij uitstek voor tussen het discriminatieverbod enerzijds en de vrijheidsrechten (...) anderzijds. Het discriminatieverbod stelt grenzen aan de gegarandeerde vrijheden of, andersom gesteld, de vrijheden bepalen mede de reikwijdte van het discriminatieverbod. Deze wederzijdse begrenzing zal ook expliciet uitgangspunt dienen te zijn van het onderwijs. (...) Scholen kunnen in het onderwijs eigen opvattingen hebben over de (wenselijke) verhouding tussen grondrechten, maar de burgerschapsopdracht brengt mee dat daarover dialoog plaatsvindt binnen de school waarbij tolerantie, positieve verdraagzaamheid en kennis van en respect voor de basiswaarden cruciaal zijn.'

Bepaalde formuleringen uit de 'oude' versie van de MvT doen denken aan het hiervoor omschreven autonomieliberalisme. Bijvoorbeeld het benoemen van 'persoonlijke autonomie' als basiswaarde, evenals het 'afwijzen van onverdraagzaamheid en discriminatie'. In het derde citaat wordt de suggestie gewekt dat vrijheidsrechten vooral worden begrensd door het discriminatieverbod en dat dit ook zo in het onderwijs moet doorklinken. De termen 'onverdraagzaamheid' en 'discriminatie' in pejoratieve zin duiden wellicht voor alle Nederlanders op een onacceptabele praktijk, maar over de invulling van die begrippen kan fundamentele onenigheid bestaan. Religies kunnen bijvoorbeeld uitgaan van een exclusieve waarheidsclaim en/of afwijzend staan tegenover bijvoorbeeld homoseksualiteit; in de context van die religie is daarmee nog geen sprake van onverdraagzaamheid of discriminatie, maar in de opvatting van bijvoorbeeld autonomieliberalen mogelijk wel. 
In de 'nieuwe' MvT zijn deze tendensen naar autonomieliberalisme grotendeels verwijderd of afgezwakt. In paragraaf 7 wordt nu duidelijk dat de waardering van de onderlinge verhouding tussen vrijheidsrechten en discriminatieverbod aan de scholen wordt overgelaten, en ook dat de toelaatbaarheidsgrens ten aanzien van discriminerende uitlatingen identiek is aan die uit het Wetboek van Strafrecht. ${ }^{41}$ In dat kader bevat de MvT een opmerkelijke verwijzing naar de rol van de rechter: ${ }^{42}$

'In gevallen waarin de inspectie handhavend zou moeten optreden omdat de school bij de invulling van de zorgplicht buiten de kaders van de rechtsstaat treedt, kan de school (...) het handhavingsbesluit voorleggen aan de bestuursrechter. (...) Daarmee bestaat ten aanzien van de voorgestelde bepaling de waarborg dat het eindoordeel omtrent eventuele spanning tussen grondrechten (...) steeds daar ligt waar dat binnen de trias politica ook thuis hoort: bij de rechtsprekende macht.'

Ik zou echter menen dat in alle gevallen waar zich een 'spanning tussen grondrechten' voordoet, de school binnen de kaders van de nieuwe burgerschapsopdracht is gebleven. Zolang er redelijkerwijs discussie mogelijk is over de waardering van de onderlinge verhoudingen van grondrechten, is er geen reden voor handhavend optreden. Er is dan ook geen reden om een rechterlijke uitspraak 'uit te lokken' over het juiste evenwicht dat op school zou moeten worden gedoceerd. Een ander onduidelijk element is de term 'respect': het wetsvoorstel instrueert scholen tot 'het bijbrengen van respect voor en kennis van de basiswaarden van de democratische rechtsstaat'. Betekent het bijbrengen van respect voor de basiswaarden dat het onderwijs qua strekking deze waarden moet stroken? Of mag een les qua strekking ook strijdig zijn met deze basiswaarden, als maar tevens naar voren komt dat deze basiswaarden ook verdedigbaar zijn en ook overweging verdienen? De term 'respect' veronderstelt het tweede, maar in de toelichting wordt consequent verondersteld dat het onderwijs niet strijdig mag zijn met de basiswaarden.

Kortom, het wetsvoorstel bevat de nodige rechtsstatelijke en ideologische spanning: ${ }^{43}$ het blijkt een balanceeract om als wetgever te preciseren wat de essentiële basiswaarden van de democratische rechtsstaat zijn. Hoe dan ook, het resultaat is een wettekst die weliswaar ruimte biedt, maar - doordat er zoveel begrippen centraal staan die voor uiteenlopende interpretaties vatbaar zijn - wei-

41 Overigens wordt hierbij ook de Algemene wet gelijke behandeling genoemd. Dit is, dunkt mij, wel problematisch, omdat deze wet grenzen stelt aan het naar buiten optreden door een school. Die grenzen zijn naar hun aard strakker dan de grenzen aan de inhoud van het onderwijs: daarbinnen mogen in beginsel andere opvattingen naar voren komen dan de keuzes in de Algemene wet gelijke behandeling.

42 MvT, p. 23.

43 Philipsen (2018) merkte reeds op dat een burgerschapsopdracht om deze reden een ingewikkelde opgave zou zijn, en stelt ook dat al te veel inhoudelijke sturing ongewenst is omdat goed burgerschap in een democratische rechtsstaat juist ook kritische opstelling tegenover de staat vraagt. 
nig helderheid geeft over de vraag wanneer de grenzen toch overschreden worden.

Vanwege deze bedenkingen bij de voorgestelde burgerschapsopdracht zou ik een bepaling verkiezen die, naast een positief geformuleerde opdracht tot aandacht voor burgerschapsonderwijs, heel concreet aangeeft welke opvattingen daarbij ontoelaatbaar zijn. Bijvoorbeeld zoals in het hiervoor door mij gegeven voorstel. Uit de MvT en het Nader rapport kan worden opgemaakt dat de minister bewust van een negatief geformuleerde bepaling heeft afgezien omdat het juist de bedoeling is dat scholen in positieve zin de leerlingen onderwijzen en vormen in lijn met de democratische waarden en dat een democratisch ethos wordt gestimuleerd. Echter, de eerste zin van mijn voorstel doet hier recht aan; bovendien is het vervolgens nader uitwerken van de thema's, waarden, vaardigheden en de 'oefenplaats' eerder op zijn plaats bij de kerndoelen, niet bij de bekostigingsvoorwaarden. ${ }^{44}$

\section{Zorgplichtbepaling}

Een element dat om vergelijkbare redenen kritische aandacht vraagt is de 'zorgplichtbepaling' uit het tweede nieuwe artikellid: 'het bevoegd gezag draagt zorg voor een cultuur in lijn met deze basiswaarden'. Het behoeft nauwelijks betoog dat het definiëren van een schoolcultuur op een juridisch verantwoorde wijze buitengewoon ingewikkeld is. Daarbij komt dat deze bepaling voor het bevoegd gezag een zorgplicht introduceert. Zorgplichten in de wetgeving (en specifiek in de onderwijswetgeving) kennen in het algemeen als achtergrond dat de wetgever in bepaalde gevallen ruime kaders wil stellen waarvan de invulling aan de normadressaat wordt overgelaten. Die ruimte in de gestelde kaders is ook in dit geval uiteraard van groot belang. Maar een belangrijk nadeel van zorgplichten is tevens de onduidelijkheid die eraan inherent is: wanneer is eraan voldaan, wanneer is voldoende zorg betracht? Die onduidelijkheid is temeer onwenselijk nu het om een bekostigingsvoorwaarde gaat. Het advies van de Raad van State was om deze reden negatief over deze zorgplichtbepaling. ${ }^{45}$ Ook in het algemeen ontraadt de Raad van State het gebruik van zorgplichten als bekostigingsvoorwaarde of deugdelijkheidseis. ${ }^{46}$

Een nauw hieraan gerelateerd risico (gelet op de praktijk omtrent andere zorgplichten in het onderwijs) is dat de Onderwijsinspectie in haar toezichtskader met allerlei verbijzonderingscriteria concretere normen zal opstellen, die echter als

Aan de hand van de voorbereidingen door het professioneel platform curriculum.nu worden naar verwachting binnenkort ook kerndoelen voor burgerschapsonderwijs geformuleerd.

45 De Afdeling wetgeving beval in plaats hiervan aan om een publieke verantwoording door het bevoegd gezag voor te schrijven; Kamerstukken II 2019/20, 35352, 4, p. 11-12. Zie over deze en dergelijke nadelen en risico's van zorgplichten in de (onderwijs)wetgeving, en voorbeelden van gevallen waarin dit leidde tot onbedoeld 'dichtregelen' in toezichtskaders: W.W. Timmer, Het doel wel gesteld. Een praktijkonderzoek naar de toepassing van doelregelgeving (diss.), Rotterdam 2011, p. 149-268.

46 A. Weggeman (directeur van de Afdeling wetgeving van de Raad van State), inleiding 'Zorgplichten in het onderwijs', gehouden op 5 april 2018 te Barneveld. 
onbedoeld en ongewenst effect hebben dat de vrijheid alsnog versplinterd raakt. ${ }^{47}$ Weliswaar kunnen deze toezichtscriteria een school formeel-juridisch niet binden, maar informeel kan dat wel gebeuren en ook kunnen deze onbedoeld als interpretatiekader fungeren en de vrijheid zodoende alsnog verder inperken dan de wetgever bedoelde.

\section{Concluderende opmerkingen}

De minister wil er helder over zijn: scholen houden maximale vrijheid bij de invulling van de opdracht tot onderwijs in burgerschap, ook om dit vanuit de eigen grondslag te doen. Toch meen ik dat dit voorstel te weinig een beroep doet op de samenleving en de scholen zelf om vanuit de diverse richtingen intrinsiek en creatief invulling te geven aan het verankeren van de democratische waarden. Dit doordat te krampachtig wordt gepoogd om vanuit de wet de nodige inhoudelijke sturing te geven. In de oude MvT worden waarden benoemd die heel gemakkelijk vanuit een omvattend autonomieliberalisme begrepen kunnen worden, en die zijn in de definitieve MvT niet geheel verdwenen. Ook de wijze waarop met veel woorden een evenwicht wordt gezocht tussen vrijheidsrechten en het discriminatieverbod roept de vraag op of de lijnen hiermee wel de 'buitenste randen' van de rechtsstaat trekken.

Tegelijkertijd blijven de voorgestelde artikelen, zowel in de aanduiding van de basiswaarden als in de zorgplicht voor een schoolcultuur, erg open en onduidelijk. Een intrinsiek verankerd democratisch ethos is te belangrijk om op te hangen aan van overheidswege gemarkeerde omvattende ethische waarden, hetzij van een postseculier nationalisme of van een autonomieliberalisme. Voor onze democratisch-rechtsstatelijke cultuur zijn religie en levensbeschouwing echter wel van groot belang, en aan de scholen zelf kan de verbinding daartussen goed worden overgelaten. Om die reden zou ik willen pleiten voor een burgerschapsopdracht in de lijn van de formulering waarvan ik aan het begin van de vorige paragraaf een proeve heb gegeven. Zowel de spanning als de onduidelijkheden die bij het voorliggende voorstel zijn gesignaleerd, zullen zich mijns inziens in beduidend mindere mate voordoen bij die meer negatief gevormde formulering. 